ISSN No. 0974-035X

An indexed refereed \& peer-reviewed journal of higher education

Towards Excellence

UGC-HUMAN RESOURCE DEVELOPMENT CENTRE

Gujarat University, Ahmedabad-380009, Gujarat, India

\title{
COPING MECHANISM DURING COVID- 19
}

\section{Dr. Awa Shukla}

\section{Abstract:}

In last almost more than 70 days of lockdown we all are observing entire / complete change in the Lifestyle of people from its roots. We all need to understand that; there is different impact in all the different classes of the society.The higher class society is staying at home with all fulfilled necessities and facilities at home. They have different ways to keep themselves engaged throughout the day as they do not face any kind of financial crisis. The other category is the middle class; which is the largest group of Indian society. This is the main group which is suffering from the other effects of corona; in my opinion. Whereas the third category is economically lower society which residence in the slams where we find over crowd, small houses, no facilities, unhygienic area, and life in a small corner of this earth.In this way, Covid- 19 has affected society differently - social, physically and mentally. The social impact is found very different.Corona has raised many questions individually, socially as well as nationally.It is very sad to see the way Media highlights the news of corona.Now with the changing time we all have accepted the New normal work pattern. We are back to work with safety practices, social distancing and more of virtual work which is entirely a different way of working. India is emerging as one of the youth empowered and innovation initiator Nation.

Keywords: Covid19, New normal, innovation initiator

Initially we said, "Jaanhai to Jahanhai" now we say "JaanbhiJahanbhi".

Ratan Tata, Jack Ma and Many other intellectuals have very beautifully quoted that presently. We have to worry about our and society's survival. If we will be able to overcome to the challenge of Corona; there will be several directions open for all of us to live.

In last almost more than 70 days of lockdown we all are observing entire / complete change in the Lifestyle of people from its roots. 
Towards Excellence: An Indexed, Refereed \& Peer Reviewed Journal of Higher Education / Dr. Awa Shukla/ Page $\underline{178-183}$

We all need to understand that there is different impact in all the different classes of the society.

The higher class society is staying at home with all fulfilled necessitiess and facilities at home. They have different ways to keep themselves engaged throughout the day as they do not face any kind of financial crisis. There is lot to say about this group. We are seeing many celebrities on TV and Social Media saying about lockdown and their engagements. Some doingworkout, household work, indoor games etc. The basic problem or difficulty with this kind of group is, they feel to be imprisoned, which is very painful for them.

The other category is the middle class; which is the largest group of Indian society. This is the main group which is suffering from the other effects of corona; in my opinion. They have limited income, limited facility; house with less facilities, unemployment, uncertainty of income, tension of future and many other unexpected questions, these people are facing during this period. This is the group which is not accessible to government helps. Also, this group doesn't get help from any social institutions or does not even wish to stand in line to take such helps. It is well said like in Gujarati: દુપી હોવા છતાં પોતાના સ્વમાનને બજારમાં ખુલ્લું નથી કરી શકતા. They are unhappy but can't display their pain in front of the society. They feel insulted in talking such keeps so not ready for the same.

Whereas the third category is economically lower society which residence in the slams where we find over crowd, small houses, no facilities, unhygienic area, and life in a small corner of this earth. Man is bound to stay at home only in this current situation. Imaginethe children and parents staying in one or two room house, since 40-45 days continuously, which leads to psychological intolerance for them. Most of them are daily wages; so life has become hell for them. They are living depending only upon the government and other agencies help in this though time. They are worried and tensed about availability of food for a single time. Kids are not allowed to move out of home and they have no single source of entertainment at home. They are taken care of by government/ social/ religious institutions. But these institutions can solve problems of their hunger. No one can take care of their other problems related to emotional, psychological, financial, social needs is difficult for us to think about it also. 
In this way, Covid- 19 has affected society differently - social, physically and mentally. The social impact is found very different. Any age group person is found saying that for the first time he/she has stayed at home, with family \&spent quality time. Few are enjoying family time, Music, Reading and other hobbies. This is the positive side of the corona effect. But at the same time there is serious mental fear of infecting from corona. To live with this constant fear is more irritating. Also, on top of it a part from all precaution, taken, new trend of work from home. All the employees may or may not have facilitative environment to work from home; online education for kids is another question? Many other such questions are there!! Doctors (private) are scared to open their clinics which has created difficulty in people getting treatment for their disease Also, we like it or not, one fact is about the people who are addicted to pan- masala, liquor, smoking etc. This is also a very big group. There is a very dark side of people suffering mentally and physically due to non-availability of the addicted items.

Corona has raised many questions individually, socially as well as nationally. Where we all need to lead a positive and strong will power lead life earlier we faced problem like pneumonia, swine flu, chickengunia etc. which were like taking. People learnt to live with these illnesses also. Corona is not going to end as a disease which we will have to accept and live by developing an active, positive and safe life style. First of all stress Management is to be done. Stay away from fake news and partial news which leads to fearful life rather than healthy and nutritive life, which is need of the hour.

We will have to implement certain practices like washing hands, sneezing with handkerchief, avoiding going in crowd, maintaining cleanliness etc. as a part of our life. All these practices will have to be implemented as individual and societal change.

The corona effect will be touching to each and every segment of the society so it is a very sensitive issue. There is a lot of awareness found in different societies and even rural belts. This social awareness is to be development at individual level also.

"One has to invest own conscious effort to solve personal and inter personal problems in order to master, minimize or tolerate this phase of COVID-19" 
It is very sad to see the way Media highlights the news of corona. Where media is simply giving hype to the rise in figures of city, state, nation and world, and giving importance to it. Now as we all know that the situation is quite clear and we all know that in future we have to live with Corona; there why to live with negative news, why not no live with positive news like compared how many people died focus on how many recovered should be given importance. Luckily, India is ahead in the recovery ratio compared to other countries. This should be given weightage, even the expert doctor should spread the news that lead to positivity very verycategorically through all the Media forms we should spread their word.

This lockdown due to Corona has now started irritating people. People have started Mental disorders, psychological misbalance, anxiety, irritation in nature which leads to unhappy and troublesome family environment instead of happy family environment. This is the time of testing a person's capacity to struggle, strong will power, family love etc., where a person expected to deal with patience and stand with the family.

Now with the changing time we all have accepted the New normal work pattern. We are back to work with safety practices, social distancing and more of virtual work which is entirely a different way of working. But with the new normal we are moving towards more of isolated and virtual world where the stress levels and stress types may be different. We also need to manage the stress.

9 ways to manage stress that can be thought of are;

$\begin{array}{lll}\text { Nature } & \text { Friends } & \text { Art } \\ \text { Prayers } & \text { Exercise } & \text { Read } \\ \text { Yoga } & \text { Time } & \text { Think positive }\end{array}$

Coping skills

We will have to follow practices like - Distraction, Groundling, Emotional Release, Self Love Thought challenge'; Access your higher self, to come out of depression and come back to our routine productive life. As we know we all have negative coping skills and positive coping skills. So we have to 
think about the positive situations and accept the situation and work to achieve the social, financial and psychological goals for our new normal life. We have to start seeing own self with different perspective. Try to get psychological transportation. Focus towards start up India,Digital India and become pro-active to reach the global standards.

India is emerging as one of the youth empowered and innovation initiator Nation. We have ample opportunities to overcome this pandemic and rebuild and revive the economy of India. We are in a phase where we have an opportunity to expose our youth to prove their ability and make India independent economically and embark our Nation Globally. Here, is the chance to adopt the start up's, become techno savvy as well as techno developing Nation and build India as an independent nation in its true sense. So let us all come together to build a New India with New Normal in this pandemic situation. 


\section{References}

Newspapers - The Times of India, Indian express, DivyaBhaskar, Gujarat Samachar, The Hindu

Various Search engines

News Channels- Aajtak, Zee News, NDTV, News 18, INDIA News

Magazines- India Today, Outlook, The Week, Frontline

\section{Dr. Awa Shukla}

Director (I/c) Students Services \&

Asst. Prof. Journalism \& Mass Communication

Dr. Babasaheb Ambedkar Open University, Ahmedabad 